animal. And the chapter comparing wild with captive animals, although superbly well argued, quite fails to consider captive wild animals. Even so, the book is an outstanding contribution to its subject.

You cannot have direct evidence of the subjective experience of any other being. In the end, to identify animal suffering you have to do a lot of research, take clues from health, physiology and behaviour, and then guess.

JON BARZDO

\title{
Survival in the Wild, by Cindy Buxton. Collins, $£ 5.95$.
}

What a debt the conservation movement owes to the wildlife photographers - coupled of course with the inventors of colour television! Their beautiful and often amazing films have opened up a new world for millions of people, and made conservationists of them, whether they realise it or not. Cindy Buxton is one of the many talented photographers who have been prepared to spend weeks and months camping in deserts, sloshing through swamps, cooped up in a sun-baked hide (where the temperature can reach an amazing $120^{\circ} \mathrm{F}$ ) or camping at $14,000 \mathrm{ft}$ in the mountains. She describes it all in a humorous self-deprecatory way, but there is no doubt of her steel and her ability to cope with problems that are inevitable -like the occasion in Kenya when the python she was filming slithered under her car and wrapped itself round the engine for extra warmth - it took her two hours of hard struggle flat on her back to unwind him - or the much worse occasion when the self-starter packed up and she had to wade three miles, rifle on shoulder, certain that 'crocs were watching our every movement', and at one point sank into a bog - fortunately only up to her neck. But the consolations, of course, for the Cindy Buxtons of this world are in the satisfaction of working in wild places and the chance of entering to some degree into the world of their subjects. After you have watched unseen, from the privacy of a hide, a malachite kingfisher or a shoebill stork right through its nesting period - and Cindy took her opportunities to make copious notes as well as films, particularly of the shoebills - you have some understanding of their world. And so perhaps have those important TV viewers.

MAISIE FITTER

Backpacking in Chile and Argentina plus the Falkland Islands, by Hilary Bradt and John Pilkington (Bradt Enterprises, \$3.95, and \$6.95) is packed with information and illustrations, much of it of value to the armchair traveller and those who use wheeled and winged vehicles for their travel as well as those who go on foot. (41 Nortoft Road, Chalfont St. Peter, SL9 0LA.)

Rivers, Lakes and Marshes (OUP, £5.50) is half an illustrated (colour) field guide to a good selection of the commoner wetland species by a team of authors, and half an 'ecological essay' on these habitats by Brian Whitton.

An Illustrated Guide to River Phytoplankton, by Hilary Belcher and Erica Swale, is a well laid-out and illustrated (black and white drawings) identification paperback published by HMSO for the Institute of Terrestrial Ecology $(£ 1.50)$.

Birds of Australia, by Pat and Peter Slater, in Warne's Observer series ( $£ 1.95)$ features 150 species (covering all families), all illustrated, mostly with colour photographs. In the same series is a revised edition of John Cleggs valuable Pond Life $(£ 1.80)$.

The biology and conservation problems of the Pigmy Hog and the Hispid Hare are examined in Special Scientific Report No. 1 of the Jersey Wildlife Preservation Trust by William Oliver based on his field research. 